\title{
Child Labour Practices And Associated Hazards In UmunaOrlu South East Nigeria
}

\author{
Chineke H.N ${ }^{1}$, Egenti N.B ${ }^{2}$, Modebe IA ${ }^{3}$, Ubajaka CF ${ }^{3}$, *Adogu P.O. $\mathrm{U}^{3}$, \\ Egwuatu $\mathrm{CC}^{4}$ \\ 1. Department of Community Medicine Imo State University Owerri. Nigeria \\ 2. Department of Community Medicine, University of Abuja, Nigeria \\ *Corresponding author \\ 3. Department of Community Medicine, NnamdiAzikiwe University, Awka, Nigeria
}

\begin{abstract}
Background: Child labour deprives children of their childhood potentials, mental and social development. It is very common in our communities and exposes them to so many dangers.

Aim: To evaluate the practice and hazards of street hawking among children in UmunaOrlu South East Nigeria. Methodology: A descriptive cross-sectional study in which data was collected from one hundred and fifty child hawkers in UmunaOrlu using semi-structured interviewer administered questionnaires. The data was collated and analyzed using Microsoft excel package. Results were presented in frequency tables, bar charts and pie charts.

Results: Most of the child hawker 89(59.3\%) were within the age group of 9 to 13years with females $87(58 \%)$ being in the majority. Most of the children attained only primary education 111 (74\%), with $84(56 \%)$ of them living with both parents. Food and other edibles were the most commonly hawked items 109(72.4\%). Twentyfour $(48 \%)$ hawked their wares after school hours while $25(50 \%)$ hawked all through the day. Twenty-four have experienced sexual harassments, out of which 6 were complicated by unwanted pregnancy. Besides, 120 expressed discontent with hawking while 51 of them have been involved in one accident or another.
\end{abstract}

Conclusion: The burden of child hawking with its attendant hazards in Orlu are quite enormous. Relevant legislations against this menace and strict enforcement of such laws are recommended.

Key words: Child labour, hazard, Street hawking,Orlu.

\section{INTRODUCTION}

A child is a young person below the legal age of consent of 18 years ${ }^{1}$. Child labour is defined as work that deprives children of their childhood potential and dignity, and that is harmful to their social and mental development ${ }^{2}$ It refers to work that is mentally, physically, socially or morally dangerous and harmful to children, and interferes with their education by depriving them of the opportunity to attend school ${ }^{3}$. Both male and female child hawkers are seen on the streets of Nigeria. ${ }^{3}$

Physical and health hazard consequences faced by children who engage in street hawking have been identified in Africa, Asia and America ${ }^{4}$. These include respiratory problems, road accidents, physical and sexual abuse such as rape, and molestation, malnourishment, extortion of income from daily sales, harassment from police, market masters and other law enforcement agents, and participation in harmful or delinquent activities $^{4}$. Indiscriminate disposal of wastes accumulated from sale of wares by hawkers may give rise to air, water and land pollution ${ }^{5}$.Furthermore, hawkers move from place to place and in the process interact with people of different health status and circumstances ${ }^{6}$. Consequently, hawkers play a key role in the spread of communicable diseases like measles, chicken pox and conjunctivitis ${ }^{6}$.The children may also face stigmatization from the members of the press, and public alienations and isolation from family members. ${ }^{7}$ Other hazards to which child street hawker is exposed include unwanted pregnancies, sexually transmitted diseases, prostitution, armed robbery, poor academic performance in school and lack of education ${ }^{7}$. The objective of this survey was to evaluate the practice and hazards of street hawking among children in UmunaOrlu, south east Nigeria.

\section{METHODOLOGY}

Study Area: The study was conducted in Umuna town in Orlu Local Government Area of Imo state, south east Nigeria. It has some tertiary institutions, markets, banks, motor parks and many private and government hospitals including the Imo State University Teaching Hospital (IMSUTH) Orlu.

Study Site:The study sites were mainly at the motor parks, beside the old market within the main roundabout, the orieugwu market and the International market and the streets.Study Population:This was comprised of child 
hawkers from the age group of 5 to $17 y$ rs.Study Design: This was a descriptive cross-sectional study of child labour practice among children involved in street hawking in UmunaOrlu.

Data collection:The study instrument was both open and close ended interviewer-administered questionnaire, which contained questions on personal data, goods hawked, reasons for hawking, problems they encounter in the streets and level and nature of interference in their education.

The hawkers were politely approached and details of the research were explained to them. A verbal consent to participate in the study was obtained. Questionnaires were then distributed and filled with the assistance of the research team members.

Data Analysis:Data was collated and analyzed using Microsoft excel of the computer. Results were presented in frequency tables, bar charts and pie charts.

Limitations: These included lack of cooperation for fear that the researchers were sent by the government with the intension to get them arrested. Some of the hawkers demanded that we bought their goods before they would cooperate.

\section{RESULTS}

In table 1 , the mean age of respondents was $11 \pm 5.4$ years, the medianage was 11.3 years and modal age group was 9-13 years with more than 59\% of respondents within this age group. Majority of the respondents were females Christians who attained primary level of education.Most of the respondents $31(62 \%)$ came from homes with more than 4 siblings.Fourty-one (82\%) of the respondents lived with their parents and only two lived with a friend. Among those who lived with their parents, $31.7 \%$ lived with single parents, especially with their mothers alone and very few their fathers.Most (72\%) of the hawkers still went to school despite their job.Table 2 shows that most of the items hawked were food items $102(72.7 \%)$.Figure 1 shows that $(70 \%)$ of the respondents were sent to hawk by their parents, with only $5 \%$ being sent by employers.Figure 2 depicts that $74 \%$ of those who hawkedwere doing so because of the money.In table 3, $72(48 \%)$ of these children hawked after school hours, while $75(50 \%)$ hawked all through the day.Figure 3 depicts the hazards experienced by the hawkers; $120(80 \%)$ of respondents had expressed regret for hawking while 51(34\%)had been involved in one accident or the other. Poor school performance and sexual harassment had been experienced by 33(22\%) and 24 $(16 \%)$ of the hawkers respectively. Twenty-one (14\%) were however happy with their job.

\section{DISCUSSION}

Most of the child hawkers were below the age of 14 years. This was similar to the findings of Adenyika et al ${ }^{5}$, in Ibadan metropolis south west Nigeria.Of the 50 respondents, 42 were from families of four or more siblings. This conformed with the findings of Ogundele et $\mathrm{al}^{7}$, which showed that large family size contributes significantly to the incidence of child abuse and neglect. A similar report by the United Nations Children's Education Fund (UNICEF)outlined large family size, wild spread poverty and growing unemployment as critical factors that contribute to child labour abuse and its consequences ${ }^{6}$. Furthermore, Dimeji et al ${ }^{2}$, reported that most of the child hawkers are from large households of about six persons, where parents have low level of education, income and occupational sales.It also confirmed the assertions of the UNICEF that a nation without present policy on population leads its citizens to uncontrolled procreation resulting in large family sizes and the children often being denied basic rights like quality education ${ }^{6}$.

The study revealed that 84 of the respondents lived with their parents, while as many as 36 lived with single parents. Single parent households are often under financial stress in their attempt to cater for the children's basic needs like feeding, clothing and education, and their inability to meet up with the demands often results in frustrations and consequent abuse of children in various forms ${ }^{8}$. Ogindele et al ${ }^{7}$, also showed that single parenthood contributes significantly to the incidence of child abuse and neglect. The study confirmed that 33 of the child hawkers performed poorly at school as evidenced by their class position in the previous school term result. Dimeji et al, observed that street hawking in developing countries has a negative effect on the level of education, school performance, class grades, and the overall literacy level of the child hawker ${ }^{2}$. Uzochukwu observed that working children have no time, energy or money to go to school. Consequently due to high demands at work, these children skip classes and their missing out education makes it impossible for them to break the chain of poverty'.

Twenty-four of the respondents have experienced one form of sexual harassment or the other with 6 of them even having unwanted pregnancies. This conformed with the findings of Tola et al ${ }^{10}$, which showed that street hawking exposes young girls to all forms of hazards, including sexual abuse, social pregnancies and sexually transmitted infections (S.T.I's). It also conforms to the assertion, that unwanted pregnancy is a social hazard of street hawking and child labour ${ }^{11}$.

One of the reasons mentioned for street hawking was to raise money for the family especially for payment of children's school fees and home feeding. This again was similar to the findings of Dimeji et al ${ }^{2}$, who observed that the low income power of parents was a reflection of the deteriorating economic situation in 
Nigeria, which has compelled many households to utilize the labour of their children in order to augment family income. It was also in line with the submission of the Global March against child labour (2001) that parents of developing countries are relatively poor and subjected to economic challenges which compel them to seek alternative sources to augment their meager income in order to make both ends meet ${ }^{4}$. Furthermore, our finding is in agreement with the outcome of study byOgundele et al ${ }^{7}$, which postulates that the economic status of parents contributed significantly to the incidence of child abuse and neglect. Some of the respondents hawked all through the day, while others did so after school hours. This was in line with the assertion byDimeji et al ${ }^{2}$, that children work at an average of four hours a day, during which they engage in the hawking of various goods along the streets.In conclusion, child street hawkers in Orlu are predominantly 14 years and below and they are exposed to some hazards like psychological discontent, accidents, poor school performance, sexual harassment and unwanted pregnancy. Quest for money, low child educational level and single parenthood appear to be among the strongest risk factors for the menace.

Improved national economy, discouraging single parenthood, declaration of free compulsory child education and poverty alleviation measures may help reduce the practice of Child Street hawking in Orlu, Nigeria.

\section{ACKNOWLEDGEMENT}

We are grateful to Okpemandu Jerry and Ohia Maureen for their assistance in data collection and to Iwuchukwu Gloria for typing the manuscript.

TABLES AND FIGURES:

Table 1: Socio-demographic characteristics of the respondents

\begin{tabular}{|c|c|c|}
\hline Parameter & Frequency & $\%$ \\
\hline $\begin{array}{l}\text { Age }(\text { years }) \\
4-8 \\
9-13 \\
14-18 \\
\text { Total } \\
\text { Mean age }=11 \pm 5.4 \text { years }\end{array}$ & $\begin{array}{l}30 \\
89 \\
31 \\
150\end{array}$ & $\begin{array}{l}20 \\
59.3 \\
20.7 \\
100\end{array}$ \\
\hline $\begin{array}{l}\text { Gender } \\
\text { Male } \\
\text { Female } \\
\text { Total }\end{array}$ & $\begin{array}{l}63 \\
87 \\
150\end{array}$ & $\begin{array}{l}42 \\
58 \\
100\end{array}$ \\
\hline $\begin{array}{l}\text { Religion } \\
\text { Christianity } \\
\text { Islam } \\
\text { Others } \\
\text { Total }\end{array}$ & $\begin{array}{l}147 \\
3 \\
0 \\
150\end{array}$ & $\begin{array}{l}98 \\
2 \\
0 \\
100\end{array}$ \\
\hline $\begin{array}{l}\text { Level of Education } \\
\text { No formal education } \\
\text { Nursery education } \\
\text { Primary education } \\
\text { Secondary Education } \\
\text { Others } \\
\text { Total }\end{array}$ & $\begin{array}{l}10 \\
3 \\
111 \\
14 \\
12 \\
150\end{array}$ & $\begin{array}{l}6.7 \\
2 \\
74 \\
9.3 \\
8 \\
100\end{array}$ \\
\hline $\begin{array}{l}\text { Current schooling status } \\
\text { Go to school } \\
\text { Do not go to school } \\
\text { Total }\end{array}$ & $\begin{array}{r}108 \\
42 \\
150 \\
\end{array}$ & $\begin{array}{r}72 \\
28 \\
100 \\
\end{array}$ \\
\hline $\begin{array}{l}\text { Number of siblings } \\
\text { No siblings } \\
1-3 \\
4-6 \\
7-9 \\
10-13 \\
\text { Total } \\
\end{array}$ & $\begin{array}{r}3 \\
24 \\
73 \\
34 \\
16 \\
150 \\
\end{array}$ & $\begin{array}{l}2 \\
16 \\
48.6 \\
22.7 \\
10.7 \\
100\end{array}$ \\
\hline
\end{tabular}




\begin{tabular}{|l|l|r|}
\hline Who the respondents are living with & \\
Mother & 36 & 24 \\
Father & 3 & 2 \\
Both parents & 84 & 56 \\
Guardian & 24 & 16 \\
Friend & 3 & 2 \\
Total & 150 & 100 \\
\hline
\end{tabular}

Table 2: Items hawked by respondents

\begin{tabular}{|l|c|c|}
\hline Items & Frequency & \% \\
\hline Food items & 109 & 72.7 \\
Newspaper & 9 & 6 \\
Jewelry & 8 & 5.3 \\
Others & 24 & 16 \\
Total & 150 & 100 \\
\hline
\end{tabular}

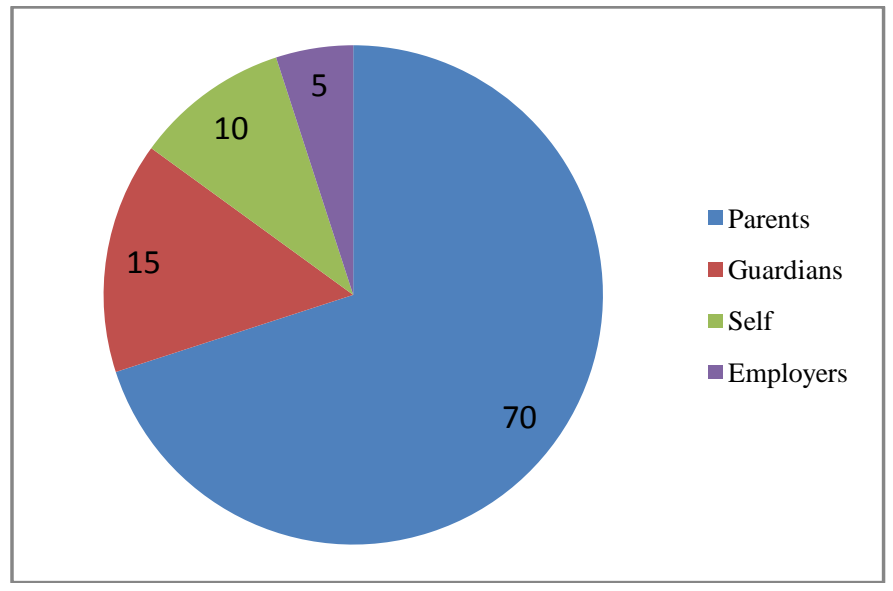

FIGURE 1: Proportion of people who send respondents to hawk

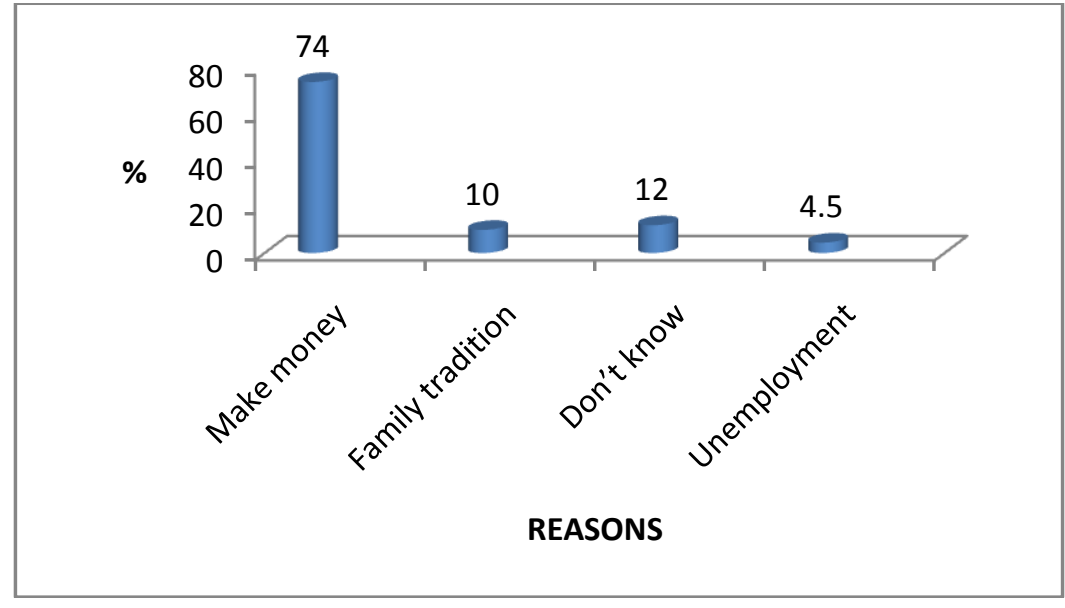

Figure 2: Reason for hawking 
Table 3: Time of the day when they normally hawk

\begin{tabular}{|l|l|l|}
\hline Time of the Day & Frequency & $(\boldsymbol{\%})$ \\
\hline After School Hours & 72 & 48 \\
All Through the day & 75 & 50 \\
No Response & 3 & 2 \\
Total & 150 & 100 \\
\hline
\end{tabular}

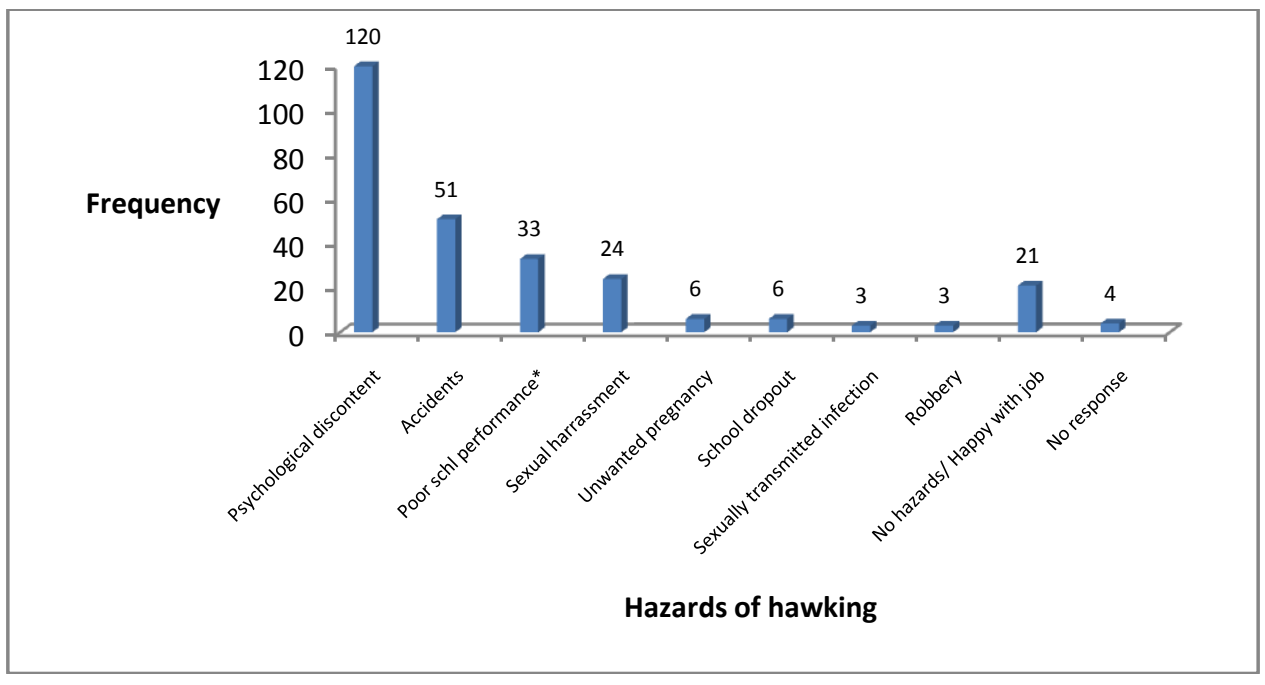

Figure 3: Hazards of hawking experienced

*As assessed from their previous term's result

\section{REFERENCES}

[1] Oxford Advanced Learner's Dictionary 2010.en.m wiki. Pedia.org/wiki/child labour (Accessed 3/10/14).

[2] Dimeji T, Arielle C. Consequences of child labour in urban Nigeria Jour SOC Sci 2008; 16(2):173-181.

[3] Osiruemu E. Poverty of parents and child labour in Benin-city Nigeria: A preliminary account of its nature and implications Jour SocSci 2007; 14(2):115-121.

[4] ILO=IPEC: Official page of Global March against Child Labour, 2001.http//www.child labour news info/. (Accessed on 16/4/2014).

[5] Adeyinka A. Social correlates and coping measures of street children: A comparative study of street and non-street children in south-western Nigeria; child Abuseand Neglect. Jour SocSci 200024(9):1119-1213.

[6] UNICEF Nigeria 2006; child labour information sheet.

[7] Ogundele BO, Ojo RA. Selected socio-demographic factors as a correlate of child abuse and neglect among parents in Ibadan, Oyo state South West-Nigeria. Ethno-med Jour 2007; (2):147-151.

[8] Stresses of single parenting. American Academy of Pediatrics. www.healthy children.org/ English/fam...(Accessed 16-9-15).

[9] Child Street Hawking: Causes, effects and solutions. UzochukwuMike.http://hubpages.com/family/ChildStreet-Hawking-CausesEffects-and-Solutions(Accessed 16-9-15)

[10] Effects of street hawking among teenage girls. Naira project.com/projects/58/htms (Accessed 16-9-15).

[11] Street Hawking.oppressing the girl child www/guestia.com/library/journal/IGI.(Accessed 16-9-15). 